\title{
PERFORMANCE MEASUREMENT OF SMALL BREEDING BUSINESS IN NORTH BENGKULU REGENCY: APPLICATION OF BALANCED SCORECARD (BSC) METHOD
}

\author{
Muly Apriansyah'1), Ketut Sukiyono²), Mohammad Chozin ${ }^{3)}$ \\ 1)Study Program of Agribusiness Magister Faculty of Agriculture, \\ University of Bengkulu \\ 2) Department of Agricultural Socio-Economics, Faculty of Agriculture, University of \\ Bengkulu \\ 3) Graduate Program of Agroecotechnology, Faculty of Agriculture, University of Bengkulu, \\ Email: ksukiyono@unib.ac.id
}

\section{How to Cite : \\ Aprianasyah, M., K. Sukiyono, M. Chozin, 2019 Performance Measurement Of Small Breeding Business In North Bengkulu Regency: Application Of Balanced Scorecard (BSC) Method. Journal of Agri Socio-Economics and Business. 1 (2): 59-72. DOI: https://doi.org/10.31186/jaseb.1.2.59-72}

\section{ARTICLE HISTORY}

Received [xx Month $x x x x]$ Revised [xx Month $x x x x]$ Accepted [xx Month $x x x x]$

\section{KEYWORDS}

Small Business

Performance,

BSC

This is an open access article under the $C C-B Y-S A$ license

\section{ABSTRACT}

The purpose of this research first is to evaluate the performance of Usaha Perbenihan Kecil (Small Breeding Businesses $=U P K$ ) from the perspective of financial, customers, internal business process, as well as learning and growth. The second objective is to identify the factors that performance in supporting the success of UPK solutions and fix the problem. Two UPKs are cencused and interviewed, namely, UPK Karya Mandiri and UPK Karya Tani. Balanced Scorecards (BSC) is applied to measure financial and nonfinancial performances. The results show that performances of two UPKS are categorized a good performance in all perspectives, with exception to MCE index. This indicates that both UPKs should continouesly improve their internal business. 


\section{INTRODUCTION}

Rubber plants (Hevea brasiliensis) are annual plants. One plant cycle calculated from the time of planting in the field to rejuvenation takes 25 years. The choice of planting material must be carefully considered because there is incorrectness in the selection of planting material which will negatively affect the plantation and the national natural rubber business (Siagian, 2012). Therefore, the supply of superior rubber seeds is very important accomplished by both the government and private companies.

North Bengkulu Regency is the center of the rubber plant Usaha Perbenihan Kecil (UPK= Small Breeding Business) ready to be distributed. The UPK has a fairly broad market share and segment, namely the community and the Provincial Government of Bengkulu through the seed procurement project. But the problem is whether UPK in serving the needs of rubber seedlings for its consumers has performed well or not, a comprehensive study needs to be conducted. The measurement of UPK performance can be viewed from financial and non-financial aspects. One approach to measuring this performance is the Balanced Score Card (BSC)as suggested by Kaplan \& Norton (2000) and Mulyadi (2001).

BSC has been applied in several studies, especially related to Small Medium Enterprises (SMEs). Widaningrum \& Kabul (2014) applied BSC to measure Restaurant Performances in Jakarta. In implementing the BSC, indicators are used by considering limitations and adjusting to the real conditions of the SMEs studied. Thus, the BSC can be used for the evaluation process of performance measurement and can achieve the desired goals. Other studies are Novitawaty (2016) in Bakery Pitaloka, Wibowo (2017) in SMEs Performances, Aspriyati, Andini \& Sukiyono (2017) in Ground Coffee Business, and Muyasowafin (2002) in coopertaive evaluation, Seth \& Oyugi (2013) in higher eduaction organization performances. These studies generally indicate that applying BSC rarely implemented in SMEs, especially in Indonesia. This will be a challenge for SMEs if they want to survive and develop their business activities.

Based on the above discussion, in which UPK is expected to continue to survive in a very tight competition, its performance measurement using BSC is significant to conduct. Furthermore, by looking at the problems faced by the rubber UPK in Bengkulu Regency, it is necessary to research to find out what performance components should be improved in the future. This can be completed by assessing aspects of UPK performance measurement. Thus, the purpose of this study is, firstly, to evaluate the performance of Small Seed Businesses (UPK) viewed from the perspective of finance, customers, internal business processes, and learning and growth. Secondly, it aims to identify the performance constraining factors to incur in UPK success of UPK and its accommodating solutions 


\section{RESEARCH METHODS}

This research was carried out at UPK Jaya Mandiri and Karya Tani located in North Bengkulu Regency and determined purposively, with the consideration that in each plantation development area it is hoped that a seedling business can grow to serve the needs of seeds. The data used in the form of primary data obtained from interviews with UPK owners, employees, and customers, as well as secondary data obtained from literature or previous research. Respondents from this study consisted of 2 UPK owners, 10 employees, and 50 customers. Analysis of the data used in this study are:

\section{Vision and Mission Analysis}

This analysis is carried out qualitatively. In the analysis of the vision, mission, objectives, and strategy of the company are translated into each measurement perspective in the concept of the Balanced Scorecard (BSC) using qualitative analysis (Djumadi 2008). This analysis was carried out to informants who were very important in this process, namely the UPK owners.

\section{Analysis of Key Performance Indicators (KPI)}

Determination of performance measures or KPIs there is two measures in achieving strategic objectives, namely the performance measure (lagging indicator) and the leading indicator. The success of achieving strategic goals is indicated by a certain measure called the outcome measure. To achieve results, performance triggers are needed, namely, the measure that causes results to be achieved (Pratiwi et al. (2009) and Yuwono, Sukarno, \& Ichsan, 2007)).

\section{Financial Perspective}

From a financial perspective, UPK performances can be measured by several financial ratios, among others, liquidity ratios, profitability ratios, profitability ratios, and solvency ratios. This measurement is intended to examine how far the SMEs have reliability in their finances. Also, this is certainly to know about the extent of SMEs' ability in terms of capital and other financial capabilities.

Financial ratio analysis used in this study consists of liquidity ratios, solvability ratios, profitability ratios, and efficiency. The liquidity ratio is calculated by the current ratio and quick ratio, then the solvency ratio is measured by debt to assets ratio, debt to equity ratio, profitability ratio by measuring the value of ROA, ROI and profit margin, and the efficiency ratio is calculated by comparing revenues and total costs (Diana \& Wasilah, 2009). 


\section{Customer Perspective}

The customer perspective in BSC allows companies to target selected market segments to succeed. The selection of appropriate market segments helps the company to design strategies that can maximize business results, in this case, a financial reward. In addition, when doing business, a company will not be able to achieve the desired performance if it does not see the needs of its customers. This leads to the creation of value that can meet client needs. Therefore, satisfied clients are one of the key components of a company's performance strategy.

The instrument of measuring customer satisfaction in this study uses a Likert scale to measure every statement in the questionnaire. Five categories are used to measure the level of customer satisfaction, namely, 5 for very satisfied, 4 for satisfied, 3 for quite satisfied, 2 for dissatisfied (2), and 1 very dissatisfied.

\section{Internal Business Process Perspective}

This perspective measurement consists of an innovation process, a production process consisting of Manufacturing Cycle Effectiveness (MCE) by comparing processing time with completion time, calculating the percentage of defective products, reworks, and so on and emphasizing costs without reducing the quality of products or services. it is very important to be done by managers following the company's strategy and goals. And after-sales service process that aims to increase customer satisfaction. This requires that the UPK must be able to establish good relationships with customers, namely by maintaining product quality so that customers remain loyal to the UPK.

\section{Learning and Growth Perspectives}

Measurements in this perspective include the level of employee satisfaction by comparing perceptual scores with expectations scores, employee retention by comparing the number of employees out with the total number of employees, employee productivity by comparing sales and number of employees, and employee training compared to the number of employees training and number of employees.

\section{Overall Analysis of Company Performance Measurement}

From all strategic measures of each perspective, namely the financial, customer, internal business processes, and learning and growth perspectives, then compared with the targets set by the company, then given a score based on the rating scale, $-1,0$, and 1 . The method used to determine the weight of each perspective is to add the total weight of the section scores of each 
perspective divided by the total sections from four perspectives, as suggested by (Timur, et al. (2014).

$$
\text { Weight }=\frac{\text { Total Strategic Side Score }}{\text { Number of Stategic Sizes }}
$$

After the weight value is known, the next step is to make a scale to assess the total score, so that the company's performance can be said to be "less" (1 scale), "sufficient" (scale 0), and "good" (scale 1). With this scale, the results of the UPK can be known. After creating a scale, then determine the area boundaries "less", "enough", and "good". Performance is said to be lacking if less than $50 \%$ (assumed $50 \%$ is equal to 0 ), performance is said to be "good" if more than $80 \%$ and assumed that $80 \%$ is equal to 0.6 . The rest are "adequate" areas, namely between 0 - 0.6 (Hanuma \& Kiswara, 2011).

\section{RESULTS AND DISCUSSION}

The UPK's vision and mission after being confirmed by the business owner, the vision of UPK Jaya Mandiri, namely "Jaya Mandiri as a community self-help group formed by the equality of rubber seed breeders in running Agribusiness to support the development of quality smallholder rubber plantations in the Bengkulu Province". And the vision of UPK Farming is "Becoming Professional Seed". While the mission of UPK Jaya Mandiri is (1) Reviewing and implementing recommended clones from the Government. (2) UPK Jaya Mandiri as a profit-oriented self-help group. For the mission of UPK Karya Tani are (1) Helping planters in finding superior rubber seeds, (2) Making aspects of professional seed management. (3) Also, support the economic direction of garden farmers. The existence of a vision and mission will make this UPK challenged to achieve its expectations, and know the steps that must be taken through the targets set. Based on UPK's vision and mission, it can be concluded that in carrying out its operations UPK strives to become a business that can face tomorrow's challenges (Mustari \& Primawati 2014). This vision and mission are oriented towards the future, where company owners will be motivated in developing their business to be better in the future and able to face various challenges both now and in the future.

\section{Strategic target}

In describing the business vision and mission, many strategic objectives will be carried out. But in this case, the determined strategic target is the target that is the top priority of the UPK to achieve the vision and mission. In determining the strategic objectives of UPK Jaya Mandiri, it refers to the prescribed vision and mission which is further elaborated in the four perspectives on the Balanced Scorecard. 
Table 1. Strategic Objectives of UPK Jaya Mandiri and Karya Tani

\begin{tabular}{|c|c|}
\hline \multicolumn{2}{|c|}{ Strategic Objectives } \\
\hline Financial Perspective & Subscription Perspective \\
\hline $\begin{array}{l}\text { a. Increased Liquidity } \\
\text { b. Increased Solvency } \\
\text { c. Increased Profit } \\
\text { d. } \text { Business Efficiency }\end{array}$ & $\begin{array}{l}\text { a. Give Satisfaction to the smallholder } \\
\text { in getting the latest recommended } \\
\text { clone choice }\end{array}$ \\
\hline $\begin{array}{c}\text { Internal Business Process } \\
\text { Perspective } \\
\end{array}$ & Learning and Growth Perspective \\
\hline $\begin{array}{l}\text { a. Improve Customer Service } \\
\text { Processes } \\
\text { b. Increase The Amount of Production } \\
\text { c. Improve Product Quality }\end{array}$ & $\begin{array}{l}\text { a. Increase Employee Satisfaction } \\
\text { b. Improve Employee Quality and } \\
\text { Capability }\end{array}$ \\
\hline
\end{tabular}

Source: Primary Data (2018)

\section{Strategy Map}

This strategic map is compiled using the four perspectives in the Balanced Scorecard, namely financial, customer, internal business processes, and learning and growth. This strategy is intended to achieve UPK Vision and Mision. In brief, the Vision and Mision of UPK can be stated as follows:

\section{UPK Jaya Mandiri:}

Vision: Jaya Mandiri as a non-governmental group formed by the equality of the profession of rubber seed breeder who in carrying out agribusiness to support the development of quality community rubber plantations in the province of Bengkulu.

Mision: (1) Reviewing and implementing government recommended clones,

(2) UPK Jaya Mandiri as a profit-oriented self-help group

UPK Karya Tani:

Vision: Become a professional seed

Mision: (1) Assisting smallholder farmers in finding superior rubber seed,

(2) Making aspects of professional seed management, (3) also support the economic discretion of smallholders 


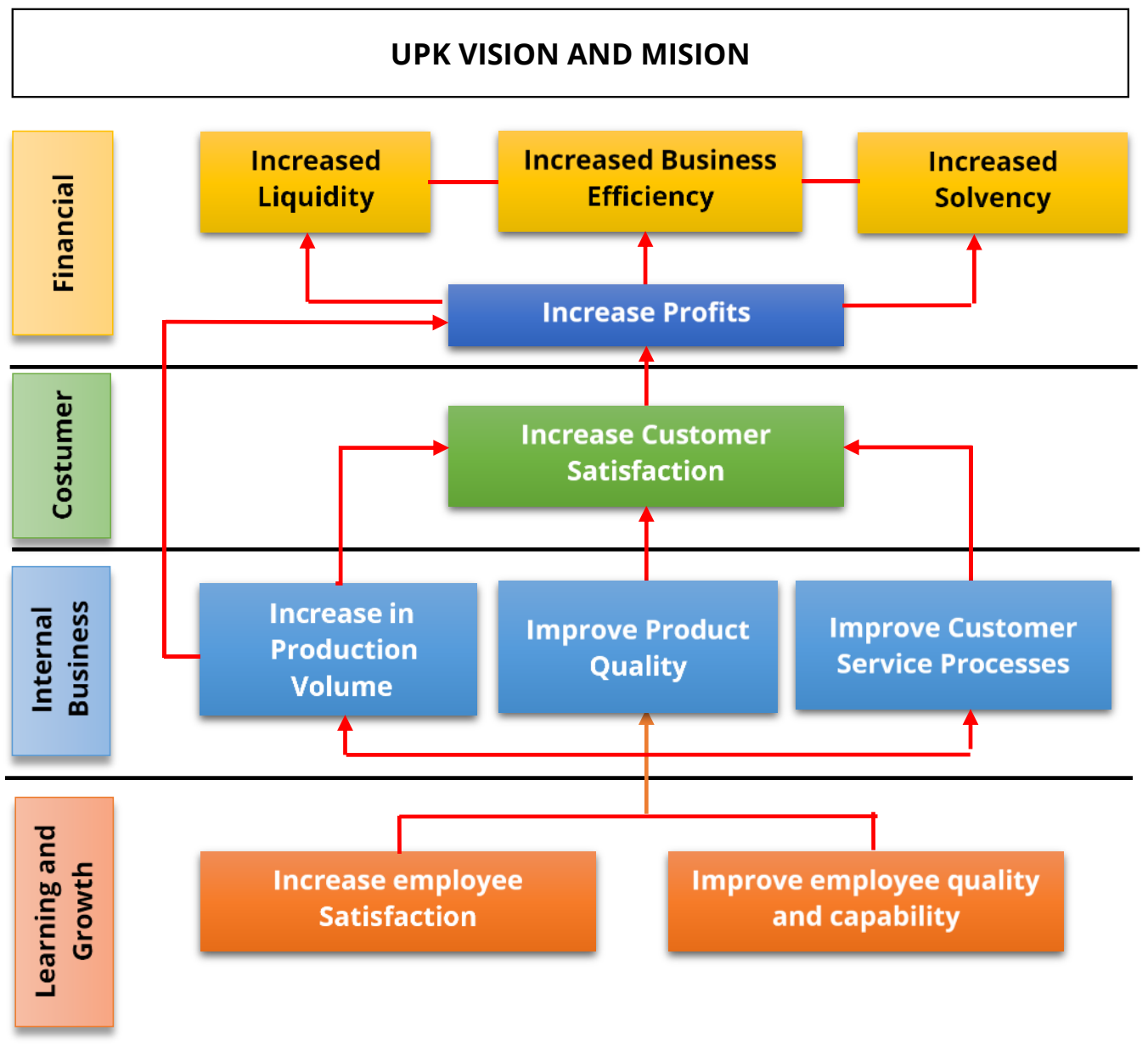

Figure 1.

Strategic map UPK Jaya Mandiri and Karya Tani

\section{Key Performance Indicators (KPI)}

The outcome measure shows the results of a strategy, which is an indicator that shows management what has happened, on the contrary, trigger size is the leading indicator, which shows the progress of the important parts of implementing a strategy according to Pratiwi 2010). The determination of KPI at UPK Jaya Mandiri has two measures, namely the outcome indicator (lag indicator) and the trigger size (lead indicator).

From the four perspectives that have strategic objectives, measurement is needed to achieve success (lag indicator). In achieving the strategic objectives sets, the results measure can describe the current state of the company. But in achieving the size of the results required a trigger size (lead indicator) or a factor driving performance. This trigger size is a measure that causes results to be achieved. 
Table 2. UPK Key Performance Indicators (KPI)

\begin{tabular}{|c|c|c|c|}
\hline \multirow{2}{*}{ Perspective } & \multirow{2}{*}{ Strategic target } & \multicolumn{2}{|c|}{ Key Performance Indicators (KPI) } \\
\hline & & Lag Indicator) & Lead Indicator) \\
\hline \multirow{4}{*}{ Financial } & Increased Liquidity & $\begin{array}{l}\text { Current ratio, } \\
\text { Quick ratio }\end{array}$ & $\begin{array}{l}\text { Current Ratio, Quick } \\
\text { Ratio > 100\% }\end{array}$ \\
\hline & Increased Solvency & $\begin{array}{l}\text { Debt to Assets Ratio, } \\
\text { Debt to Equity Ratio }\end{array}$ & $\begin{array}{l}\text { Value DAR \& DER < } \\
100 \%\end{array}$ \\
\hline & Increased profit & $\begin{array}{l}\text { ROA, ROI, Profit } \\
\text { Margin }\end{array}$ & $\begin{array}{l}\text { Increased revenue } \\
\text { and reduced costs }\end{array}$ \\
\hline & $\begin{array}{l}\text { Increased Business } \\
\text { Efficiency }\end{array}$ & $\mathrm{R} / \mathrm{C}$ ratio & $\begin{array}{l}\text { Increased profits and } \\
\text { reduced costs }\end{array}$ \\
\hline Costumer & $\begin{array}{l}\text { Customer } \\
\text { Satisfaction }\end{array}$ & $\begin{array}{l}\text { Customer response } \\
\text { survey }\end{array}$ & $\begin{array}{l}\text { Increased customer } \\
\text { satisfaction }\end{array}$ \\
\hline
\end{tabular}

Increase production Innovation process

\begin{tabular}{|c|c|c|c|}
\hline $\begin{array}{l}\text { Internal } \\
\text { business }\end{array}$ & $\begin{array}{l}\text { Improve customer } \\
\text { service processes }\end{array}$ & $\begin{array}{l}\text { (MCE) } \\
\text { Product damage }\end{array}$ & $\begin{array}{l}\text { Production } \\
\text { time }\end{array}$ \\
\hline & Improve quality & After-sale process & \\
\hline $\begin{array}{l}\text { Learning } \\
\text { and Growth }\end{array}$ & $\begin{array}{l}\text { Increase employee } \\
\text { satisfaction } \\
\text { Improve employee } \\
\text { quality and } \\
\text { capability }\end{array}$ & $\begin{array}{l}\text { Increase employee } \\
\text { response } \\
\text { Employee retention } \\
\text { and employee } \\
\text { productivity }\end{array}$ & $\begin{array}{l}\text { Improve employee } \\
\text { performance } \\
\text { employee skills } \\
\text { income }\end{array}$ \\
\hline
\end{tabular}

Source: Primary data, (2018)

\section{UPK Performance Measurement}

From a financial perspective, the outcome measures used to achieve strategic objectives include the current ratio, quick ratio, debt to asset ratio, debt to equity ratio, ROA, ROI, profit margin, and R/C ratio. To achieve the target of increasing liquidity, the results of measurements in 2016 and 2017 show the current ratio of $1616 \%$ and $1624 \%$, meaning that every IDR 1 short-term debt is guaranteed to be IDR 1,616 and IDR 1,624 by current assets at UPK Jaya Mandiri and 526\% and 512\% means that every IDR 1 short-term debt is guaranteed IDR 5.26 and IDR 5.12 by current assets respectively.

From the financial perspective, the results of the results in 2016 and 2017 all financial performance get a good category. So that, the score is 1 . These results indicate that everything planned by the management of UPK Jaya Mandiri has produced financial performances as targeted. From the customer perspective measuring customer satisfaction, it also produces good criteria with score of 1 . High 
customer satisfaction also informs us that the quality of the products produced by UPK Jaya is in accordance with the needs of consumers. Not only that, the services provided by UPK Jaya Mandiri also do not disappoint so that this service can satisfy consumers.

The internal business process has also good criteria. This perspective includes inovation process, MCE index, Defective products, and after-sales servises. All these measurement have good performaces with exception of MCE index. The low MCE index is reasonable because the supply of seeds that are ready for planting requires sufficient time.

Table 3. Performance Measurement Results of Each UPK Jaya Mandiri Perspective

\begin{tabular}{|c|c|c|c|c|c|c|c|}
\hline Perspectives & Outcome Measures & 2016 & Target & 2017 & Target & Performance & Score \\
\hline \multirow{8}{*}{ Financial } & Current Ratio (\%) & 1616 & 100 & 1624 & 100 & Good & 1 \\
\hline & Quick Ratio (\%) & 1530 & 100 & 1544 & 100 & Good & 1 \\
\hline & DAR (\%) & 95.06 & 80 & 94.73 & 80 & Good & 1 \\
\hline & $\operatorname{DER}(\%)$ & 21.43 & 10 & 13.84 & 10 & Good & 1 \\
\hline & ROA (\%) & 216 & 100 & 264 & 100 & Good & 1 \\
\hline & ROI (\%) & 216 & 100 & 264 & 100 & Good & 1 \\
\hline & Profit Margin (\%) & 69 & 70 & 72 & 70 & Good & 1 \\
\hline & R/C Ratio & 4.22 & 1 & 4.44 & 1 & Good & 1 \\
\hline Costumer & $\begin{array}{l}\text { Customer Satisfaction } \\
(\%)\end{array}$ & 98 & 100 & 98 & 100 & Good & 1 \\
\hline \multirow{4}{*}{$\begin{array}{l}\text { Internal } \\
\text { business }\end{array}$} & Innovation Process & 315,000 & 300,000 & 343,600 & 300,000 & Good & 1 \\
\hline & MCE Index & 0.98 & $>1$ & 0.98 & $>1$ & Fair & 0 \\
\hline & Defective Product (\%) & 6 & 10 & 6 & 10 & Good & 1 \\
\hline & After-Sale Service (\%) & 0.02 & 0.1 & 0.01 & 0.1 & Good & 1 \\
\hline \multirow{3}{*}{$\begin{array}{l}\text { Learning } \\
\text { and Growth }\end{array}$} & $\begin{array}{l}\text { Employee Satisfaction } \\
\text { (\%) }\end{array}$ & 98 & 100 & 98 & 100 & Good & 1 \\
\hline & Employee Retention & 0 & 0 & 0 & 0 & Good & 1 \\
\hline & $\begin{array}{l}\text { Employee Productivity } \\
\text { (stem/MH/cyclus) }\end{array}$ & 63.000 & 50.000 & 68.720 & 50.000 & Good & 1 \\
\hline & Total & & & & & & 16 \\
\hline
\end{tabular}

Source: Primary Data (2018)

Comparing Tables 3 and 4, it appears that UPK Jaya Mandiri has a slightly better performance than UPK Karya Tani. From 4 perspectives, the performance of the two UPKs is relatively the same, except in the internal business perspective where UPK Jaya Mandiri has better performance. This can be seen from the outcome measures where UPK Jaya Mandiri's defective produc is better than UPK Karya Tani. For other outcomes, the two UPKs have the same performance, only the business scale that distinguishes the two, where the UPK Jaya Mandiri has a larger scale than the UPK Karya Tani. 
Table 4. Performance Measurement Results of UPK Karya Tani Perspective

\begin{tabular}{|c|c|c|c|c|c|c|c|}
\hline Perspective & Outcome measures & 2016 & Target & 2017 & Target & Performance & Score \\
\hline \multirow{8}{*}{ Financial } & Current ratio (\%) & 526 & 100 & 512 & 100 & Good & 1 \\
\hline & Quick ratio (\%) & 526 & 100 & 226 & 100 & Good & 1 \\
\hline & $\operatorname{DAR}(\%)$ & 48 & 50 & 73 & 50 & Good & 1 \\
\hline & DER (\%) & 10 & 10 & 20 & 10 & Good & 1 \\
\hline & ROA (\%) & 85 & 40 & 37 & 40 & Good & 1 \\
\hline & ROI (\%) & 85 & 40 & 37 & 40 & Good & 1 \\
\hline & Profit Margin (\%) & 52 & 10 & 29 & 10 & Good & 1 \\
\hline & $\mathrm{R} / \mathrm{C}$ ratio & 1,30 & 0,5 & 0,63 & 0,5 & Good & 1 \\
\hline Costumer & $\begin{array}{l}\text { Customer Satisfaction } \\
(\%)\end{array}$ & 100 & 100 & 100 & 100 & Good & 1 \\
\hline \multirow{4}{*}{$\begin{array}{l}\text { Internal } \\
\text { business }\end{array}$} & Innovation process & 21.000 & 20.000 & 31.000 & 20.000 & Good & 1 \\
\hline & MCE indeks) & 0,98 & 1 & 0,98 & 1 & Fair & 0 \\
\hline & Defective product (\%) & 48 & 10 & 38 & 10 & Less & -1 \\
\hline & After-sale service (\%) & 0,05 & 0,1 & 0,03 & 0,1 & Good & 1 \\
\hline \multirow{3}{*}{$\begin{array}{l}\text { Learning and } \\
\text { Growth }\end{array}$} & $\begin{array}{l}\text { Employee satisfaction } \\
(\%)\end{array}$ & 98 & 100 & 98 & 100 & Good & 1 \\
\hline & Employee retention & 0 & 0 & 0 & 0 & Good & 1 \\
\hline & $\begin{array}{l}\text { Employee productivity } \\
\text { (stem/MH/cyclus) }\end{array}$ & 4.200 & 1.000 & 6.200 & 1.000 & Good & 1 \\
\hline \multicolumn{2}{|r|}{ Total Skor } & & & & & & 16 \\
\hline
\end{tabular}

Source: Data primer diolah,

2018

After each measurement result has been reported, it can be seen how many scores each perspective has. The results are compared with the number of measurements from the four perspectives so that the weight of UPK performance is obtained. From these weight values, UPK performance criteria were obtained by using a performance scale.

Table 5. Overall Performance of UPK Jaya Mandiri

\begin{tabular}{lcc}
\hline \multirow{2}{*}{ Perspectives } & \multicolumn{2}{c}{ Score } \\
\cline { 2 - 3 } & UPK Jaya Mandiri & UPK Karya Tani \\
\hline Finansial & 8 & 8 \\
Costumer & 1 & 1 \\
Internal business & 4 & 4 \\
Learning and Growth & 3 & 3 \\
\hline Total & $\mathbf{1 6}$ & $\mathbf{1 6}$ \\
\hline
\end{tabular}

Source: Primary Data, 2018

In table 5, the total score obtained from the four perspectives is 16 . While the total strategic variables or measures from each perspective are as many as 15 ,

68 | Mully Apriansyah, Ketut Sukiyono, Muhammad Chozin; Performance ... 
including financial perspectives there are 8 outcome measures, customer perspectives are 1 outcome measure, internal business process perspective 4 outcome measures, and learning and growth perspectives have 3 results. Furthermore, from the total score of 16 obtained compared to the total strategic size of 14 , so that we obtain a value of the weight of 0.9 . Furthermore, on the scale of performance area boundaries "less", "enough", and "good". The area boundary is to find out the UPK performance criteria obtained. Where the value of the performance weight of UPK Jaya Mandiri, which is 0.9 , means that the performance at the UPK is said to be "good" because the value reaches $90 \%$. From these results, it can be said that the performance of UPK Jaya Mandiri in 2017 using the Balanced Scorecard method has been "good".

Total scores from the four perspectives are 16. While the total strategic variables or measures from each perspective are 13, covering 8 financial perspectives, there is 1 outcome measure, the customer perspective is 1 outcome measure, there are 3 internal business process perspective results, and learning perspectives and growth has 3 outcome measures. Furthermore, from the total score of 16 obtained compared to the total strategic size of 13, we obtain a weight value of 0.81 . Furthermore, on the scale of performance area boundaries "less", "enough", and "good". The area boundary is to find out the UPK performance criteria obtained. Where the value of the performance of UPK Karya Tani, which is 0.9 , means that the performance at the UPK is said to be "good" because the value is more than $80 \%$ and assumed $80 \%$ is equal to 0.6 (Hanuma and Kiswara, 2011). From these results, it can be said that the performance of UPK Karya Tani in 2017 using the Balanced Scorecard method has been "good"

\section{Strategy Recommendations}

Based on overall performance measurement, Small Seed Business has a good performance category. As for the results of the measurements made, the researcher recommends strategies that can be applied by the UPK in the future, namely as follows:

\section{Financial Perspective}

Based on the size of the strategic perspective, it has good performance, judging by the value of the score given. So from that strategic step that UPK is doing is maintaining more performance for financial position and financial ratios, especially in terms of generating profits, going forward.

\section{Customer Perspective}

In this second perspective, UPK should provide better services and meet customer expectations in the future. Based on the measurements made, the value of customer satisfaction at the Karya Tani UPK is still below $100 \%$, which means that UPK services are still not meeting customer expectations. By 
further improving its services, customers will be very satisfied and will certainly have a positive impact on the UPK.

\section{Internal Business Process Perspective}

The recommendation from this perspective is that the UPK proposes to the government to propose high-yield blocks as a source of rootstock so that it does not need to bring more rubber seeds as rootstock material from other provinces and build as many forest gardens as possible.

\section{Learning and Growth Perspective}

From the results of performance measurement in this fourth perspective, the ability to retain employees is very good. If the UPK can maintain its employees well and as long as possible, then all production activities will be easy to run and there is no need to worry about failures because the experience of the employees is sufficient.

\section{CONCLUSIONS AND RECOMMENDATIONS}

\section{Conclusion}

Based on the results and discussion it can be concluded that:

1. Small Seed Business Performance (UPK) using the Balanced Scorecard method produces good performance seen from:

a. Financial perspective, UPK must maintain financial position and financial ratios in generating profits, and increase sales so that the UPK profit is higher.

b. The customer perspective, UPK should provide better service according to customer expectations and expand the product marketing area.

c. From the perspective of internal business processes, the UPK proposed with the government to create a source garden of high-producing blocks as a base material as rootstock and multiply the garden of trees.

d. Learning and growth perspective, UPK must improve its ability to retain employees, and improve employee productivity by increasing sales of products produced.

2. Performance inhibiting factors in supporting the success of the UPK in the internal business process perspective, especially on the level of product damage.

\section{Recomedations}

UPK needs to improve internal business processes, especially in the process of product damage, because the less damage the products produced, the greater the benefits. 


\section{REFERENCES}

Aidi -Daslin. 2005 . Kemajuan pemuliaan dan seleksi dalam menghasilkan kultivar karet unggul. hlm. 26-37. Prosiding Lokakarya Nasional Pemuliaan Tanaman Karet 2005, Medan, 22-23 November 2005. Balai Penelitian Sungei Putih, Pusat Penelitian Karet, Medan.

Aspriyati, W. Andani, A dan Sukiyono, K. 2017. Pengukuran Kinerja Perusahaan Kopi Bubuk "Sahabat" di Lubuk Linggau : Aplikasi Balanced Scorecard (BSC). AGRISEP 16(2): 177 - 190.

Dunia, F. A dan Wasilah. 2009. Akuntansi Biaya. Salemba Empat. Jakarta.

Hanuma, S., dan Kiswara, E. 2011. Analisis Balanced Scorecard Sebagai Alat Pengukur Kinerja Perusahaan (Studi Kasus pada PT Astra Honda Motor).http://eprints.undip.ac.id/26355/1/JURNAL.pdf.Diakses tanggal 13 Februari 2017.

Kaplan, R., S. dan David P. Norton. 2000. Balanced Scorecard: Menerapkan Strategi Menjadi Aksi. Erlangga. Jakarta.

Mulyadi. 2001. Balanced Scorecard: Alat Manajemen Kontemporer untuk Pelipat ganda Kinerja Keuangan Perusahaan. PT Salemba empat. Jakarta.

Mutasowafin, A. 2002. Penerapan Balanced Scorecard Sebagai Tolak Ukur Penilaian Pada Badan Usaha Berbentuk Koperasi. Jurnal Universitas Paramadina Vol. 1 No.3. mei 2002: 245-264.

Novitawaty, Tria. 2016. Pengukuran Kinerja Usaha Kecil Menegah Dengan Metode Balanced Scorecard: Studi Kasus pada UKM Bakery Pitaloka. Program Studi Teknik Industri Fakultas Teknologi Industri Universitas Islam Indonesia Yogyakarta. (Skripsi)

Pratiwi, Umi. 2010. Balanced Scorecard dan Manajemen Strategik. Jurnal Manajemen dan Akuntansi Fakultas Ekonomi Universitas Soedirman, 11 (2):166-174.

Primawati, A., \& Mustari, D. (2014). Analisis Manajemen Proyek Perangkat Lunak Sistem Informasi Akuntansi Pada Biro Sistem Informasi PT. X. Jurnal Sistem Informasi, 9(2), 101-106. https://doi.org/10.21609/jsi.v9i2.358

Seth A. and Oyugi L. A.2013. Influence of Balanced Scorecard on Organizational Performance in Institutions of Higher Learning in Kenya. A Case Study of University of Nairobi. International Journal of Education and Research Vol. 1No. 8 August 2013

Siagian, N. 2012. Pembibitan dan Pengadaan Bahan Tanam Karet Unggul. Balai Penelitian Sungei Putih. Pusat Penelitian Karet. Medan

Timur, A. P., Santoso, I., dan Effendi, M. 2014. Penilaian Kinerja Perusahaan Dengan Menggunakan Balanced Scorecard (Studi Kasus pada Score Cafe, Malang). 
Jurusan Teknologi Industri Pertanian, Fakultas Teknologi Pertanian, Universitas Brawijaya, Malang.

Wibowo, Edi Wahyu. 2017. Kajian Analisis Kinerja Usaha Mikro Kecil Menengah (UMKM) Dengan Menggunakan Metode Balance Scorecard. JURNAL LENTERA BISNIS. 6 (2):25 - 43.

Widaningrum, D. L., dan Kabul, I. 2014. Implementasi Balanced Scorecard Pada Unit Usaha Kecil Menengah: Studi Kasus Sebuah Restoran di Jakarta. Comtech. 5(2): 1031 - 1040.

Yuwono, Sony, Edy Sukarno, Muhammad Ichsan. 2007. Petunjuk Praktis Penyusunan Balanced Scorecard: Menuju Organisasi yang Berfokus pada Strategi. Jakarta: PT Gramedia Pustaka Utama. 